\title{
Terrorism: from Ethnic Cleansing to Lone Wolves
}

\author{
Paul Dumouchel \\ Ritsumeikan University, Kyoto, Japan
}

\begin{abstract}
Terrorism takes many forms and numerous actions which at first resemble terrorism are not defined as such and others which are quite different, are described as acts of terrorism. Why? This paper argues that different forms of terrorism are related to the changing structure of the modern state and especially that the close resemblance between many acts of terrorism (especially by lone wolves and mass murders) is related to the transformation of the state's monopoly of legitimate violence.
\end{abstract}

\section{Keywords}

Terrorism; Lone wolves; Ethnic cleansing; Rohingyas; Political Violence; Sovereignty.

\section{Introduction}

The systematic and brutal expulsion of Muslim Rohingya from Myanmar carried out by the country's army, helped by local villagers and hired thugs, encouraged by nationalist Buddhist monks, tacitly approved by the Nobel Peace prize recipient and de facto head of state, Aung San Suu Kyi, cannot be described as other than state terrorism. This is an orchestrated campaign of terror with burned villages, rapes and murders aiming to chase people away from their homes, an entire population forced to flee. To date, close to one million Rohingyas (more than 800,000 by the latest estimates) have sought refuge in Bangladesh. This large-scale operation is a form of terrorism that requires the mobilization of important resources, and a centralized direction. As Stanley Tambiah showed long ago, collective violence is never the result of spontaneous riots or of popular uprisings, it requires the coordination of numerous people. ${ }^{1}$

\footnotetext{
1 Stanley J. Tambiah, Levelling Crowds. Ethnonationalist Conflicts and Collective Violence in South Asia (Berkeley: University of California Press, 1996). More precisely argues Tambiah, "spontaneous" riots and popular uprising are always organized and lead by professionals of violence, the police, the army or hired thugs.

This is an Open Access article distributed in accordance with the Creative Commons Attribution Non Commercial (CC-BY-NC-ND 4.0) license, which permits others to copy or share the article, provided original work is properly cited and that this is not done for commercial purposes. Users may not remix, transform, or build upon the material and may not distribute the modified material (bttp:// creativecommons.org/ licenses/by-nc/4.0/)
} 
At the other end of the terrorist act spectrum, we find the recent murder outside the Saint-Charles train station in Marseille of two young women by a knife wielding attacker shouting "Allah Akbar." This form of terrorism is quite different. These are isolated murders committed single-handedly by a "lone wolf," a solitary individual, acting alone, often outside of any chain of command and without logistic support from an organized body. It is the action of an individual commonly described as "self-radicalized." Why do these two sociologically very different phenomena both qualify as terrorism? What makes them similar?

Is it only because both involve violence and aim to instil fear that they are called terrorism? On October 11, 2017 in Las Vegas, a sixty-four-year-old retired accountant opened fire with semi-automatic weapons from the thirty-second floor of a hotel on the crowd gathered below for a music festival. Fifty-eight persons had been killed and more than five hundred were wounded, many of them critically. Police say that there is no known connection between the assailant who apparently committed suicide and any terrorist organization. $^{2}$ In his declaration after this tragedy, the president of the United States declined calling it an act of terrorism. Why?

Why do we call the first two events terrorism, but not the third? There really are two questions here. The first one is: why do we call "terrorism" such different events as a massive campaign of administrative violence organized by a state and isolated murders committed by a lone self-radicalized individual? The second is: why do we not call terrorism mass murders like the one which happened recently in Las Vegas, or the one which took place in Charleston in 2015 where the gunman claimed racist white supremacist motivations for his act? In other words, why do we call terrorism events which at first sight seem quite different and why do we refuse to call terrorism other events that seem to be very similar to some that we do call terrorism?

It is true that in the United States in particular, branding mass murders like the one which just took place in Las Vegas as terrorism would go (or can be seen as going) against the interest of the powerful gun lobby; thus, this may result in the reticence to call terrorism such violent incidents, no matter how terrible they are. However, this very argument presupposes the existence of a broadly-recognized fundamental difference between two forms of social violence, between, albeit atrocious, insane, mindboggling crimes and terrorism. What is it? What makes terrorism different from a simple crime? One evident answer is that terrorism is a form of political violence. Yet, taken by itself, this claim is pretty much equivalent to saying that political violence is different because it is political, which may be true, but not exactly informative unless the claim is further analysed. What is it that makes political violence different? Why and how is it different?

In the remainder of this paper, I will first argue that political violence is different because it constitutes either a challenge to the state's monopoly of legitimate violence or a response to such a challenge, as in the case of state terrorism. Secondly, I will argue that many recent terrorist attacks, especially those of self-radicalized terrorists and free entrepreneurs, cannot be understood independently of the ongoing transformations of the modern state, more precisely that Western democracies are progressively abandoning what

\footnotetext{
${ }^{2}$ It is true that Isis claimed responsibility for the attack, saying that the perpetrator had converted to Islam a few months before, there seems however to be no indication that this is the case.
} 
until now has been the central characteristic of the modern state: the monopoly of legitimate violence. Until recently, terrorist acts could be defined as attacks on the state monopoly of legitimate violence, but now that states are progressively relinquishing their monopoly of legitimate violence, as I will argue later on, the meaning of terrorist actions is changing, they cannot anymore simply be understood as challenges to the state's monopoly of violence.

\section{Political Violence}

Violence can be defined as political to the extent that it becomes legitimized through the simple fact that it has been committed. ${ }^{3}$ Political violence is legitimized by its occurrence, in the sense that it is enough for that violence to be committed for it to be recognized as legitimate. At the basic level of the action itself, there is no difference between political violence and other forms of violence; a murder, a rape, a theft, or bank robbery is just that, under any circumstance: a murder, a rape, a theft or bank robbery. The difference between political violence and criminal violence emerges not from the action itself but from how the violent act is perceived and understood by the public at large. Violence becomes political when a sufficient number of people recognize themselves in the violent action; and think that the act was in some way justified, or that the victims (to some extent) deserved what happened to them. In the absence of such a recognition, violence, whatever its motivation, remains purely criminal. What is important here is not the subjective opinion of the perpetrators, or even of third party observers, but their reaction to the violence which is not the same thing as their opinion. That is to say, their assessment that the violent action is in some way justified should not be understood as preventing these same third parties from simultaneously rejecting the violence for moral, political, strategic or other reasons. The level of endorsement of the violence may vary immensely. Nonetheless, in every case, the positive evaluation of the violent action is what lends it a political dimension that it would not have otherwise. In its absence, the violent action is simply a crime. ${ }^{4}$

Political violence then is violence that also functions as displaced or surrogate violence. What marks a violent act as political is that many persons who are not directly concerned by it (as either victims or perpetrators) make that violent action their own. They identify with it. Following René Girard's analysis of sacrificial violence, ${ }^{5}$ political violence is violence that some individuals endorse, but not commit themselves, and that functions as a substitute and outlet for their own violence. Thus, political violence is a form of sacrificial violence in a society where sacrifice has disappeared and has been replaced by the state as the central institution. The modern state is characterized by its monopoly of legitimate violence. This monopoly does not simply entail that the state enjoys supremacy in the use of violence within a given territory. It is essentially moral: the monopoly of legitimate violence means that the state's violence and only the state's violence is legitimate. The modern state has

\footnotetext{
3 Paul Dumouchel, The Barren Sacrifice (East Lansing: Michigan State University Press, 2015). See also Paul Dumouchel, «Violence politique et vérité» in L'Homme est né libre, ed. Josiane Boulad-Ayoub (Sainte-Foy, Québec: Presses de l'Université Laval, 2014), 206 - 2002.

${ }^{4}$ At least that is the case in a society where the state holds the monopoly of legitimate violence.

${ }^{5}$ René Girard, Violence and the Sacred (Baltimore: Johns Hopkins University Press, 1977).
} 
captured, to the exclusion of every other institution, the moral authority to distinguish between good and bad violence. Of course, many instances claim to have the ability to discriminate between the two: religions, social analysts, even newspapers, but only the state can enact that distinction, to the extent that the state alone can prescribe legitimate violence.

As Max Weber, ${ }^{6}$ who coined the definition of the modern state, realized, the state's monopoly is only possible because it is generally recognized. The supreme power of the state does not rest on exceeding force, rather its supreme force rests on the agreement of those who are subjected to it. In The Barren Sacrifice, I proposed a mimetic analysis of this phenomenon. As in the scapegoat mechanism, what is involved here is the unanimous transfer of each one's violence unto a unique bearer. This transfer is what makes the violence of the state legitimate. The mechanism which makes the violence of the state legitimate is thus the same which makes political violence political except that in the case of the state the transfer is unanimous, or nearly unanimous. This unanimity transforms the perception of violence. Unanimously recognized, good violence does not appear as violence any more, but as something else: the legitimate use of force. Any violence that challenges the state's moral monopoly of legitimate violence is political, all challenges to the state's claim to be uniquely able to distinguish between good and bad violence tends to be seen by it as violent, no matter how peaceful it may be.

\section{Ethnic cleansing}

Given the above definition of political violence, it may seem surprising to claim that an operation of ethnic cleansing carried out by a state against part of its population constitutes "state terrorism." Why is it not just the state's exercising its monopoly of legitimate violence? To put it otherwise, if political violence is a challenge to the state's monopoly of legitimate violence, and if terrorism is a form of political violence, how is state terrorism possible? The answer is implicit in what was said in the previous paragraph. The state's violence becomes political, rather than correspond to the legal exercise of its monopoly, when it gains its legitimacy from the simple fact that it was committed, rather than because it is a legal act of the state. The distinction may seem a little subtle, as it is to some extent similar to the distinction between a sacrificial crisis and between sacrifice as an institution. The point is that in going against its recognized legal authority, the state is in fact trying to re-found its monopoly of legitimate violence. This attempt to re-found its monopoly of legitimate violence on the part of the state resembles the founding violence of the sacrificial crisis which, according to Girard, is at the origin of the sacred authority to distinguish between good and bad violence. Furthermore, in cases like this one there are clear empirical signs that allow one to make the difference.

Among many indications that a state is resorting to political violence and terrorism, two are particularly evident and easy to recognize. The first is when in response to a challenge to its legitimacy, the state resorts to forms of violence that transgress its own rules concerning the use of legitimate violence. In other words, if it acts illegally. In doing so, the state

\footnotetext{
${ }^{6}$ Max Weber, The Vocation Lectures (Indianapolis: Hackett Publishing, 2004).
} 
recognizes that its own legitimacy is insufficient and seeks a re-foundation of its moral claim through the direct use of a form of violence likely to be unanimously approved - that is approved by all, except the victims. The second is when those who would normally censure the state for this transgression of its rules (such as the opposition figures and parties, wellknown critics, newspapers, figures of independent moral standing, etc.) either remain silent or approve of the government's action. This shows that the state's appeal to a direct legitimacy beyond its normal institutions succeeds. That is to say, their abandon of the critical stance indicates that the state's normal legitimacy is no more an issue and that it is effectively gaining legitimacy for its violence from the simple fact that it has been perpetrated.

The ongoing crisis in Myanmar, the administrative violence that has created hundreds of thousands of refugees is an excellent example of this phenomenon. First, it is evident that the violence is illegal from the fact that in relation to the international community, the state claims that it does not have anything to do with it, that the army is in no way involved in the burning of villages, rapes, and assassinations and that all this is being done by the Arakan Rohingya Salvation Army (ASRA). Second, traditional critics of the state from Buddhist monks, to independent journalists and, of course, Aung San Suu Kyi, either endorse the violence or claim that it is not happening. It should be clear the violence is legitimizing the army's monopoly of legitimate violence, as well as the fact that it is also displaced, sacrificial violence.

It would be wrong to believe that the Rohingyas pose any serious threat to the holder of the monopoly of legitimate violence in Myanmar. ${ }^{7}$ That holder, or rather the main claimant to that monopoly in Myanmar remains the army, in spite of the fact that in 2011 (after nearly 50 years of military rule) the ruling junta was dissolved, and a civilian government came to power. ${ }^{8}$ Actually, the challenges to the army's monopoly of legitimate violence came from two sources. The first one regards Buddhist monks who staged the so called "Saffron Revolution" of 2007 which ultimately led to the 2008 constitutional revision that initiated the transition to civilian rule. The second one is Aung San Suu Kyi herself, Nobel Peace prize winner, leader of the National League for Democracy and since 2016 State Counselor, which is more or less the equivalent to the position of Prime Minister.

Note that both challenges are essentially moral and do not in any way involve violence. They are challenges to the army's ability to make the distinction between good and bad violence, but they are not attempts to enact that distinction in its stead through acts of violence. The first challenge, of Buddhist monks, dates from 2007 when the army lost part of its legitimacy by violently repressing protests led by monks against economic hardships. While Buddhism is traditional in Myanmar, Aung San Suu Kyi's moral authority comes to a

\footnotetext{
${ }^{7}$ Even if the recent violence began after the Arakan Rohingya Salvation Army (ASRA) claimed attacks on police and army posts. This insurgent force is quite small and estimated to have about 500 soldiers in all.

${ }^{8}$ Many international analysts consider that the transition to civilian rule has in fact allowed the army to entrench itself more deeply in Myanmar's politics.
} 
large extent from the international community. ${ }^{9}$ Her fight for democracy in Myanmar has received support from nearly every democratic leader in the world. Unlike other national politicians, she commands world respect and her internationally-based moral authority allowed her to more or less become head of state even though she is, according to the Constitution, barred from being president.

The Rohingyas have been excluded from citizenship since the independence of Burma in 1947. They constitute a pariah group and are considered foreigners although many Rohingya settlements have existed for centuries. Recent (since the transition to civil rule) attempts to grant them legal recognition have been successfully opposed by Buddhist nationalists. There are strong anti-Muslim prejudices in Myanmar and in the past few years many Buddhist monks have been fomenting "spontaneous" violence against the Rohingyas. By more or less taking over or participating in this violence, the army regains the legitimacy it had lost by violently opposing the actions of Buddhist monks. Simultaneously, Aung San Suu Kyi, by tacitly approving this violence, for whatever reasons - political strategy, personal prejudice or simple incapacity to stop it - is destroying her international moral authority, which is the only thing she ever had that really distinguished her from other national politicians. As a result, she will from now on be in no way able to challenge the army's monopoly of legitimate violence. Her only means of power had always been her moral authority.

The situation is the following in Myanmar: there is an agent, the army, who commands the means of supreme violence, but has been losing the moral authority that alone transforms this force into law. The present violence, against a defenceless third party whom everyone seems ready to consider as the enemy, can be seen as an attempt to regain that moral authority. Whether or not this will succeed and the extent to which it is a conscious strategy of the army rather than simply an opportunistic reaction are open questions. Whichever the case, it is clear that violence, in this case, as in that of insurgency, seeks the support of third parties, that is of social agents who are neither victims nor perpetrators. State terrorism is violence that aims to re-found the state's monopoly of the use of legitimate violence, while terrorism represents violent attempts to challenge that monopoly.

\section{Lone Wolves Terrorists}

In New and Old Wars, ${ }^{10}$ Mary Kaldor argues that many recent developments indicate that states are progressively losing the monopoly of legitimate violence. She insists on two in particular. One is the integration of many states' military into international alliances, like NATO, which make it extremely difficult or impossible for any of these states (except superpowers) to wage war independently. The second is the growing importance of private security companies, mercenaries and soldiers of fortune who are increasingly employed by states, and by various non-state actors in different conflicts. Both phenomena are

\footnotetext{
${ }^{9}$ To a large extent but not entirely, since she is the daughter of Aung San, former Prime minister who is considered the Father of the Nation and who was assassinated six months before independence in 1947.

${ }^{10}$ Mary Kaldor, New and Old Wars, $3^{\text {rd }}$ edition (Stanford, CA.: Stanford University Press, 2012).
} 
important, but Kaldor understands them more as obstacles to the state's ability to exercise supreme violence than as signs of states abandoning their moral authority to make the distinction between legitimate and illegitimate violence. Quite the opposite, I want to insist that the state is also relinquishing its moral authority.

At least four or five recent and closely-related developments suggest that a deep alteration of the modern state is taking place. First, the "outsourcing Sovereignty" should be highlighted. This refers to delegating essential functions of the state to private enterprises, dealing with issues as different as the military, immigration, law enforcement, disaster relief, prisons, border control, ports and airports security; and the list is not exhaustive. ${ }^{11}$ Modern states in Europe and in North America are surrendering to private entrepreneurs the right to take decisions and to perform functions which were considered, until recently, exclusively their own and which in many cases include the use of coercive force.

The second development, as already mentioned, is the rise of security companies and private armies, of "soldiers of fortune" active in international conflicts, either employed by states, by various private enterprises, or self-employed. For example, during the invasion of Iraq, the second largest contingent in the "coalition of the willing" was not British, as often claimed, but was comprised of private security companies which added to more than three times as many men as the U.K. had on the ground. In both Iraq and Afghanistan, as was already the case during the Bosnian war in ex-Yugoslavia, most combatants where non-state actors, private militias, local tribes or warlords. Even more importantly, the American security contractors in Iraq properly functioned as "outlaws" since they were neither subject to Iraqi law nor to military law as enforced by military police. They were independent. Nonetheless, their actions could lead to major changes in military strategy as it happened in Fallujah in 2004. ${ }^{12}$

The third development is the growing importance of security concerns in law enforcement and state policies. Security protection authorizes the sanctions of non-criminal behaviours to the extent that they are considered dangerous. But by whom are they considered dangerous? Ultimately, by anyone who feels threatened or intimidated by the presence, action or even the clothing of someone else. This extends the scope of the authorized use of coercive force in ways that blur and weaken the distinction between its legitimate and illegitimate use. The problem is that if resorting to excessive force by private or public agents in the context of security protection can lead to apologies and to the compensation for the harmed party, it cannot easily constitute a crime in spite of the complete innocence of the victim. The root of the difference lies in the fact that security concerns do not need to rest on facts, but merely on expectations. Whether what was expected later happens or not is entirely irrelevant to justifying the use of force. As long as the expectations are rational, as long as there is some reason to fear, the use of force will be justified even if it is later revealed that it was disproportionate, and the fear was unfounded.

The fourth development is the growing number and importance of out of court settlements. Out of court settlements do not apply the law, they result from negotiations that reflect the relative force of the parties involved, rather than they protect the rights of

\footnotetext{
11 Paul R. Verkuil, Outsourcing Sovereignty (New York: Cambridge University Press, 2007).
}

12 See Mary Kaldor, New and Old Wars, 167. 
one or the other, as is clearly shown by the fact that most include important non-disclosure clauses. The settlement is to remain invisible, which is the exact opposite of the public character of law. Such agreements sanction inequalities of power between agents. Inequalities in power whose influence the modern state's monopoly of legitimate violence traditionally used to constrain through the universal application of the law.

Finally, the lack of gun control, especially in the United States of America but also in many other states, allows citizens to resort to lethal force whenever they feel their life may be threatened. These laws indicate that these states are abandoning and passing onto the ordinary citizens what has been the central moral prerogative of modern states: its ability to make the distinction between legitimate and illegitimate violence.

All these developments suggest that the state is not only losing its ability but is actually also abandoning its moral authority to make the distinction between legitimate and illegitimate violence. This is not because modern liberal democracies have suddenly decided to rest their power on force only, but because their citizens have become convinced that it is not the duty of the state to make that distinction - though it is clear that states still continue to enact it, to a large extent. Citizens tend to increasingly believe that this distinction should be made at the individual level. They, and the political deciders who approve of this transformation, expect that the distinction would largely be made in the same way by all, and that a democratic state should reflect individual choices and preferences, or rather opinion concerning the distinction between good and bad violence. What the growing importance of these four elements - security concerns, outsourcing of Sovereignty and the exercise of violence, out of court settlements and "stand your ground" laws - reflect, is that the power holders of modern liberal democracies also tend to view the issue in this same way: They believe that citizens should have the right to make the distinction between legitimate and illegitimate violence.

"Terrorists," religious or otherwise just as legal security companies are private entrepreneurs of violence, individuals who take into their own hands the right to distinguish between good and bad violence. Their violence and the way in which they are recruited are closely related to the recent transformations of the state; they reflect its progressive relinquishing of its moral authority to distinguish between good and bad violence. Lonewolf terrorism and the recruitment of terrorists are inseparable from the way in which the state now understands and practices its role of protecting us against our own violence. Many religious terrorists are described as "self-radicalized," just like many fundamentalists are "born again." In both cases, we are dealing with a new form of sociality which presupposes modern individualism, rather than traditional attachments. Being "born again" or "self-radicalized" indicates that one is not born into a radical group, and that being radicalized is not the result of belonging to a given community. Quite the opposite: that belonging to a community of violence is the result of individual choice - a choice which make individuals distance themselves from the established forms of religion, in which they were born. Religion, as many have argued, can be seen as a special institutionalization of 
the sacred that is closely linked to the rise of the modern state. ${ }^{13}$ They correspond to the transformation of the sacred that takes place when the state gains the moral monopoly of legitimate violence. ${ }^{14}$ Self-radicalized agents abandon the religions that have traditionally been upholding the state's moral authority. They seek a personal answer to the question of what constitutes good, legitimate violence, one which they can chose, and which is not given to them by either birth or the state. This is particularly clear in the case of "lone wolves," who commit acts of violence in support of a group or ideology, but outside of any command structure and without any or with very little material assistance from any group. Lone wolf terrorists are radical individualists, and so are Western jihadists who leave their country to go and fight in the Middle East. They are on a personal quest.

Furthermore, their violence is essentially private, rather than properly political, or even religious. It is private and not political in the sense that such violence does not seek the approval of third parties, of others who are neither perpetrators nor victims. Nor is it an episode in a civil war or aim at toppling the government. Lone wolves are motivated by private grievances: lack of respect towards the Prophet, bombings of women and children in Syria or Iraq, support for Israel, ecological depredation, abortion legislation, protesting the presence of foreigners, revenge for the treatment of Muslims, indignation regarding a nearby gay night club, etc. These terrorist acts are, depending on the reason invoked, described as "political," "religious," "white supremacist," or simply "crazy," but in all cases, they are essentially forms of individual protest. This often remains true even when they present themselves as part of a conflict between groups.

The reason for this is that the groups with which lone wolves identify have almost entirely abandoned political objectives. Many of these groups are more akin to bandits (for example the FARC guerrillas in Colombia were deeply involved in drug trafficking, or the Tamil Tigers in Sri Lanka were doing in contraband) than to what we usually imagine political rebels to be, and they generally include many convicted criminals in their ranks. ${ }^{15}$ The goal of these various private militia, is not so much to establish themselves in a territory and to gain legitimacy in the eyes of the population or to topple the government, but to control important resources such as oil, diamond, or drug trade or some other source of revenue. In order to do that, it is not necessary to gain legitimacy but simply to destroy the rule of law and to maintain power through violence, as also argued Mary Kaldor. This destructive strategy is what returning jihadist and self-radicalized terrorists apply in our societies. We should remember however that the resulting weakening of the rule of law is also the results of long term decisions on the part of modern states and of the way they react to terrorism.

\footnotetext{
13 Talal Asad, Formations of the Secular: Christianity, Islam, Modernity (Stanford, CA.: Stanford University Press, 2003). See also Daniel Dubuisson, The Western Construction of Religion: Myths, Knowledge, and Ideology (Baltimore: John Hopkins University Press, 2003).

${ }_{14}$ Paul Dumouchel, "The Modern State and the Myth of 'Political Violence"', in The European Wars of Religion, ed. Wolfgang Palaver, Harriet Rudolf \& Dietmar Regensburger (New York: Routledge, 2016), 185-196. See also note 13.

${ }^{15}$ See Mary Kaldor, New and Old Wars, especially chapter 2.
} 


\section{References}

Asad, Talal. Formations of the Secular: Christianity, Islam, Modernity. Stanford, CA.: Stanford University Press, 2003.

Dubuisson, Daniel. The Western Construction of Religion: Myths, Knowledge, and Ideology.

Baltimore: John Hopkins University Press, 2003.

Girard, René. Violence and the Sacred. Baltimore: Johns Hopkins University Press, 1977.

Dumouchel, Paul. "Violence politique et vérité". In L'Homme est né libre, ed. Josiane BouladAyoub, 265-281. Sainte-Foy, Québec: Presses de l’Université Laval, 2014.

Dumouchel, Paul. The Barren Sacrifice. East Lansing: Michigan State University Press, 2015.

Dumouchel, Paul. "The Modern State and the Myth of 'Political Violence". In The European Wars of Religion, ed. Wolfgang Palaver, Harriet Rudolf \& Dietmar Regensburger, 185196. New York: Routledge, 2016.

Kaldor, Mary. New and Old Wars, $3^{\text {rd }}$ edition. Stanford, CA.: Stanford University Press, 2012.

Tambiah, Stanley J. Levelling Crowds. Ethnonationalist Conflicts and Collective Violence in South Asia. Berkeley: University of California Press, 1996.

Verkuil, Paul R. Outsourcing Sovereignty. New York: Cambridge University Press, 2007.

Weber, Max. The Vocation Lectures. Indianapolis: Hackett Publishing, 2004.



The PJCV Journal is published by Trivent Publishing. 